\title{
NEW TECHNOLOGICAL CONCEPT FOR THERMAL SPRAY PROTECTIVE COATINGS
}

\begin{abstract}
Thermally spraying with micro-jet cooling is an innovate technology. It is possible to get fine dispersive structure of coatings during the shorter time in comparable to the classical high velocity oxygen fuel process (HVOF). It corresponds with good corrosion-erosion properties of structure. In the paper the parameters of the spraying with micro-jet cooling process are presented. The selected properties of coatings obtained by hybrid method are presented. The results of wear tests for hybrid and HVOF coating are compared. Results of investigation are very optimistic. The presented technology should be adapted to the actual production of protective coating for machines and construction working in wear conditions.
\end{abstract}

Keywords: cooling system, micro-injector, technological concept

\section{Introduction}

The choice of materials and coatings for use in specific conditions should include [1-4]:

- identifying the types and factors causing wear;

- $\quad$ defining the requirements of the substrate material (chemical composition, temperature applications, the surface condition and so on);

- definition of tasks and technical requirements for the coating (cost, maximum wear, and the like).

In turn, the factors determining the choice of technology applying surface layers are, e.g.[1-4]:

- the possibility of given type material application and produce the desired structure of the chosen technology;

- type of the element and protected area as well as the shape of protected elements;

- the efficiency and economy of the process - the production time of coatings and material, energy consumption, real cost;

- qualifications and experience of persons performing protection.

Influence of the spraying technology on the protective properties of the coatings has been the subject of many studies [1-6]. Generally we can say, that the resistance of coatings to complex corrosion-erosion wear conditions resulted primarily from the chemical composition of the coating and its structure (Fig. 1). The structure was determined by the type of technology used spraying [1-6].
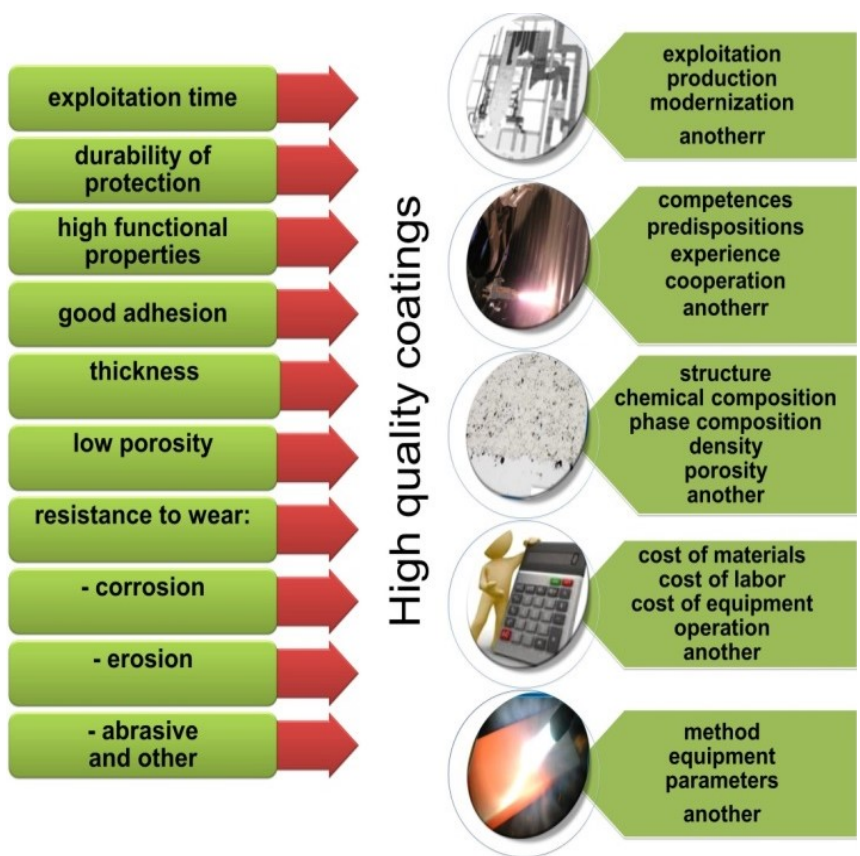

Fig. 1. Quality of coating

The coatings with a homogeneous fine dispersive morphology structure and low porosity have got improved protective properties. It has been shown, that the materials do not differ in chemical composition, or a similar chemical composition, after any other method of applying showed different resistance to wear. Currently, there are three main directions of develop-

\footnotetext{
* HIGHER SCHOOL OF LABOR SAFETY MANAGEMENT IN KATOWICE. 8 BANKOWA STR., 40-007 KATOWICE, POLAND

** BIALYSTOK UNIVERSITY OF TECHNOLOGY, 45C WIEJSKA STR., 15-351 BIAŁYSTOK, POLAND

\# Corresponding author: j.piwnik@pb.edu.pl
} 
ment of thermal spray techniques to obtained the coatings with high utility properties in short time. The first direction is the development of techniques designed to give maximum speed of the particles of the coating material, while limiting the temperature of the stream (i.e. Design modifications guns). Another is to obtain layers with the lowest porosity (e.g. laser melting, the use of modern systems and methods for spray - e.g. type HVAF supersonic, high velocity air-fuel). The third direction of development of thermal spray techniques is to use additional treatments and equipment's to modify the process of cooling the coating and to determine the state of stresses in layers. The presented idea of new hybrid spraying method is part of this trend. In this paper, the presented method and selected results are only reconnaissance research and be continued in research project [1-7].

\section{The idea of hybrid spraying method combined the high velocity oxy fuel process and micro-injector cooling system}

Nowadays there are many devices for the supersonic thermal spray. The various guns characterized construction, it has got different the point of entry of the coating material, a type of combustion chamber (closed or open), the type of control used fuel and oxidant. They are many form of materials to spraying process they are used for high velocity oxygen fuel process. (Fig. 2.) $[2-3,6]$.
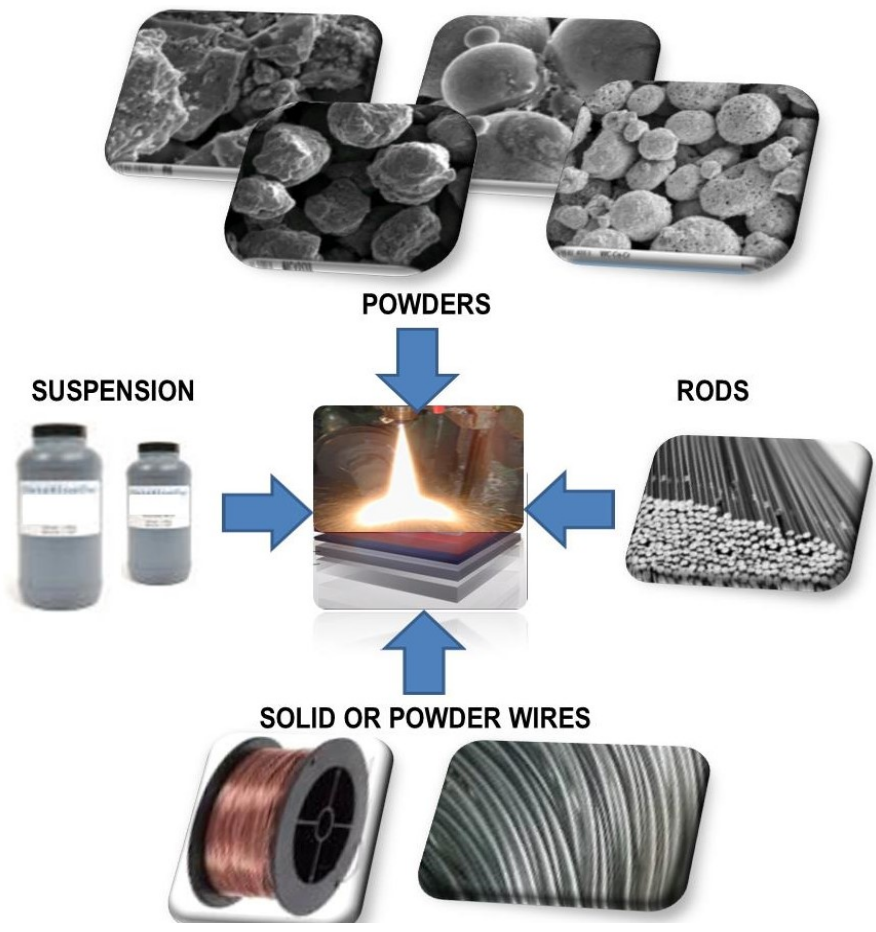

Fig. 2. Form of materials to spraying process [6]

The ultrasonic spraying coating processes, such as high velocity oxygen fuel (HVOF) thermal spray, are widely used to obtained protective coating for construction and elements working in critical wear, such as bearing races, valves and turbine components and landing gears. During the HVOF process, molten composite or ceramic droplets are sprayed from a gun onto a part. The coating is applied in layers and the process of powder spraying must be repeated. In the process of applying the surface layer is used thermokinetic energy. The energy is required to melt the powder and acceleration of the material in the gas. This leads to significant heat input to the target surface. Efficient removal of this heat load during the thermal spraying process is critical to prevent overheating of both the coating and the substrate.

For this purpose, the authors decided to join presented in publications two methods: micro-jets and HVOF [7-10]. It was assumed that suitably selected micro-injectors and processing parameters provide adequate heat dissipation of the applied surface and thus reduce thermal stresses]. The new technology allow to shorten spraying process and obtain the desired structure of the material [6,11-18].

The existing cooling processes using a stream of compressed air may cause oxidation of the applied particles. In addition, residual moisture and hydrocarbons in the cooling air have a detrimental effect on the quality of the coating. Developed and presented in publications micro-injectors are compatible with existing spraying system, so the presented micro-injector can be successfully used as new equipment for high velocity oxy fuel spraying process [17].

The new hybrid method allows for fast, precise reduction of surface temperature, immediately after spraying process and thus shortens the time between operations. The time reduction in process translates into lower consumption of: powders materials, energy, machinery and equipment. The number of micro-injector and their diameters (measured in $\mu \mathrm{m}$ ) are chosen depending upon the spraying process, so as to enable highly accurate to regulate the temperature decrease. The cooling process requires unconventional methods of measuring able to determine precisely the intensity of heat exchange between the surface layer of coating and micro-gas-stream. The force of selected cooling medium (liquid, gas) is extremely precise [17]. The idea of thermally spraying with micro-jet injector shown in Fig. 3.

The article is limited to a comparison of selected structural and wear properties of coatings made modern hybrid method using different variants of diameter of cooling equipment.

\section{Materials to research}

The base composition of coating material is $\mathrm{NiCr}-\mathrm{Cr}_{3} \mathrm{C}_{2}$. The used spraying methods were: high velocity oxygen fuel method (HVOF) - classical method and hybrid method of spraying, including HVOF and micro-jet cooling system.

The speed of the gun in relation to the substrate is maintained such that the thickness of the film after one pass the gun was $1 \mu \mathrm{m}$. Parameters and kind of thermally sprayed process are presented in Table 1 . 


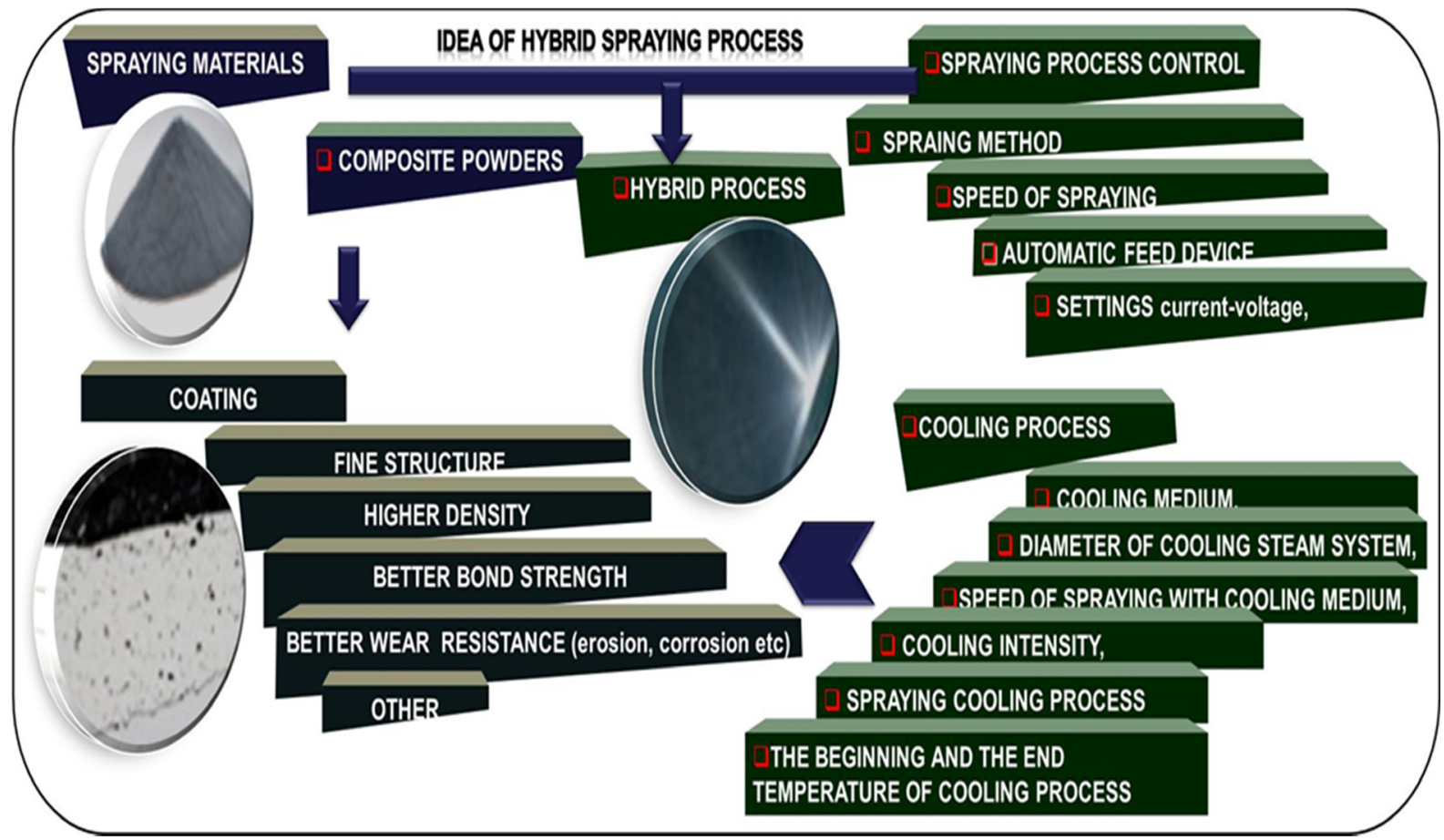

Fig. 3. The idea of micro-jet spraying process

TABLE 1 of $50 \mu \mathrm{m}$ ) or B 40 (consisting of two micro-steam diameter of

The signify of composite coatings

\begin{tabular}{|c|c|c|}
\hline \multicolumn{3}{|c|}{$\begin{array}{l}\text { Established properties of nickel chrome matrix coatings, modified } \\
\text { by chromium carbides: good corrosion resistance in high and very } \\
\text { high temperature, good erosion and abrasion resistance in ambient } \\
\text { and high temperature }\end{array}$} \\
\hline Process & $\begin{array}{l}\text { Coatings } \\
\text { Signify }\end{array}$ & $\begin{array}{l}\text { Parameters and kind of thermally sprayed } \\
\text { process }\end{array}$ \\
\hline \multirow{2}{*}{ HVOF } & S1 & \multirow{6}{*}{$\begin{array}{l}\text { - voltage in the range of } 25 \div 30[\mathrm{~V}] \\
\text { - the intensity of } 150 \div 250[\mathrm{~A}] \\
\text { - the distance of HVOF spraying was } 0.25 \\
\pm 0.03[\mathrm{~m}] \\
\text { - the distance of gun with cooling micro- } \\
\text { injector was } 0.30 \pm 0.03[\mathrm{~m}] \\
\text { - velocity of gases is above of } 2000[\mathrm{~m} / \mathrm{s}] \\
\text { - the speed of the gun with micro-jet nozzle } \\
\text { regard to the sample was about of } 0.5[\mathrm{~m} / \mathrm{s}]\end{array}$} \\
\hline & S2 & \\
\hline \multirow{4}{*}{$\begin{array}{l}\text { Hybrid } \\
\text { method }\end{array}$} & $\mathrm{S}_{1} \mathrm{~A}_{40}$ & \\
\hline & $\mathrm{S}_{2} \mathrm{~A}_{40}$ & \\
\hline & $\mathrm{S}_{1} \mathrm{~A}_{50}$ & \\
\hline & $\mathrm{S}_{2} \mathrm{~A}_{50}$ & \\
\hline
\end{tabular}

The hybrid cooling system included HVOF and micro-jet process efficiently and uniformly cools thermally sprayed coatings. The monitoring of temperature of the cladding coating is controlled by operation system. Composite coatings was carried out on the semi-automated spraying station equipped with a cooling micro-injector system. The position passed the tests, which confirmed the results published in [1]. The speed control of the gun with micro-jet cooling system was automatically controlled using a programmer and adapted to the spraying parameters specified by the manufacturer of powder material. During the process, the spraying element position (heat-resistant steel) was of $0.3 \mathrm{~m}$ from the torch and set perpendicular angle. The microinjector type A40 (consisting of one micro-steam diameter of $40 \mu \mathrm{m}$ ) was used for the spraying process. The another injector, like as type A50 (consisting of one micro-steam diameter $40 \mu \mathrm{m}$ ) are not recommended to use after the spraying process. The authors investigations shown, that the obtained coatings after cooling by micro-injector type A50 and B50 characterized exfoliation or cracking in wear tests (Fig. 4).

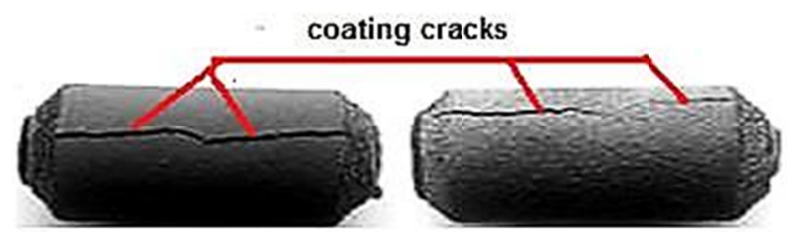

Fig. 4. View on the coatings sprayed on steel rollers by hybrid method with injector type B40 consisting of two micro-steam diameter of $40 \mu \mathrm{m}$

The obtained coatings by high velocity oxy - fuel method and hybrid method with micro-injector A40 were investigated according with the plan presented in Fig. 5. The reconnaissance investigations included: measurement of thickness and hardness, study of macrostructure and microstructure of coatings by LM (light microscopy) and SEM (scanning microscopy) and the wear tests (abrasion, erosion and corrosion tests).

The abrasive tests were carried out on the T-07 tester. All tests were performed under the same conditions and the same pressure force $-22 \mathrm{~N}$. During the tests, the sample was mounted in special holder. The tests assured suitable pressure force to the rotating counter sample. The given speed for counter sample was of 600 in the first test and of 900 in the second test. The diameter of the disc was $\mathrm{d}=50 \mathrm{~mm}$. Abrasive falling between the sample and the rotating disc caused wear of the surface layer of the sample. The difference in weight (measured samples before and after the test) determined the consumption of coatings materials. 
The erosion tests were carried out on K-01 tester, presented in Fig. 6. During the test in elevated temperature, the flame of the burner heated up the sample to a temperature of $650^{\circ} \mathrm{C}$. At this moment, the alumina sand was thrown on the sample. Sandblasting process was continued until the sample reached a temperature of $600^{\circ} \mathrm{C}$. Then the flame again heats the sample at $650^{\circ} \mathrm{C}$. The process was cyclical as long as the abrasive was in K-01 tester. After this process, the sample is cooled to a temperature of 40 degrees and will be removed.

Other parameters of erosion test were:

- distance between the nozzle and the sample $-4 \mathrm{~cm}$,

- angle of incidence of abrasive $-30^{\circ}$,

- weight abrasive $-200 \mathrm{~g}$ alumina,

- the temperature range for a sample of $680-600^{\circ} \mathrm{C}$.

The periodical corrosion test was carried out on the hightemperature corrosion station, presented in Fig. 7. The parameter of process were: annealing temperature $-800^{\circ} \mathrm{C}$, exposure time: $24,48,72$ and 120 hours. The parameters were controlled by HT industry programmer and registered on the computer.

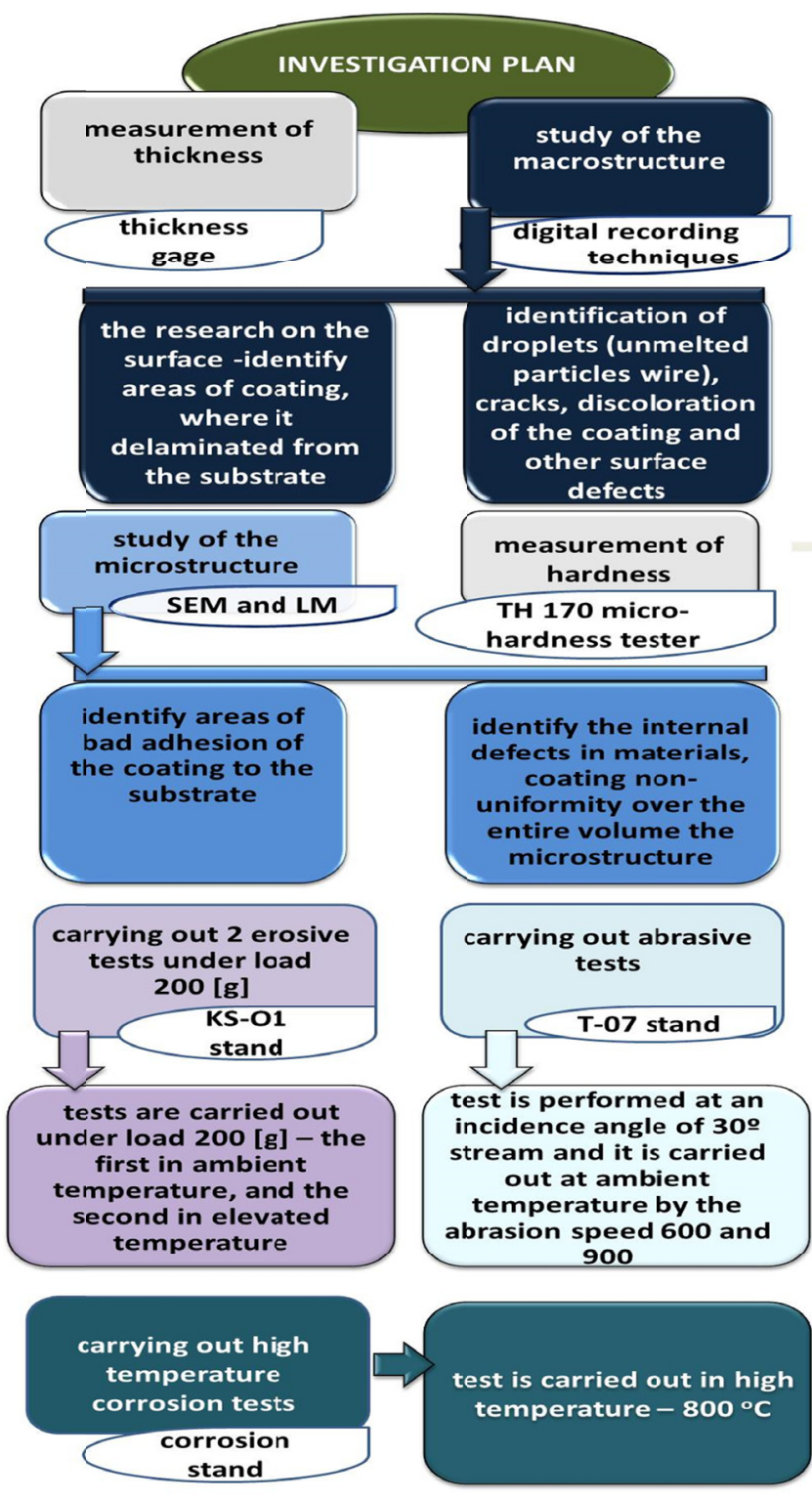

Fig. 5. Investigation plan

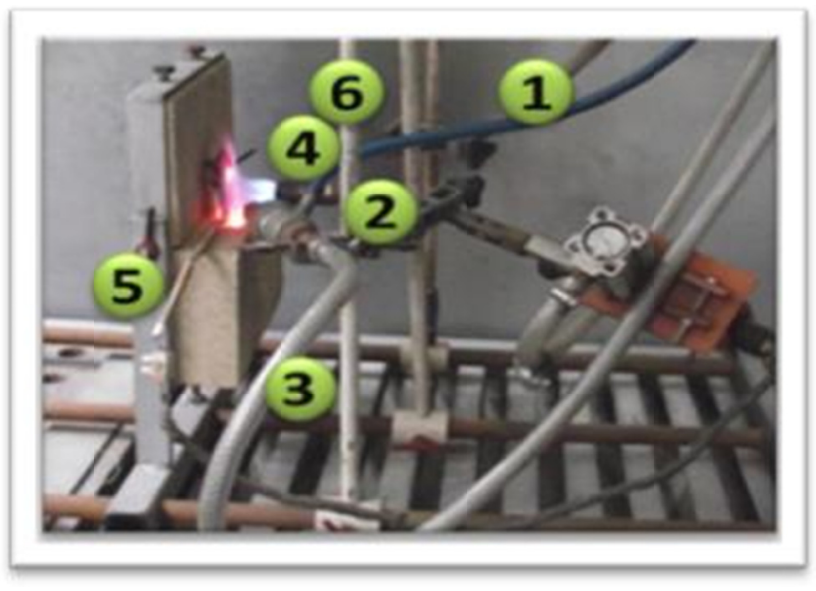

Fig. 6. View on KS-01 stand: applying abrasive (1), nozzle (2), compressed air (3), burner (4), thermocouple (5), cooling nozzle(6) [1]

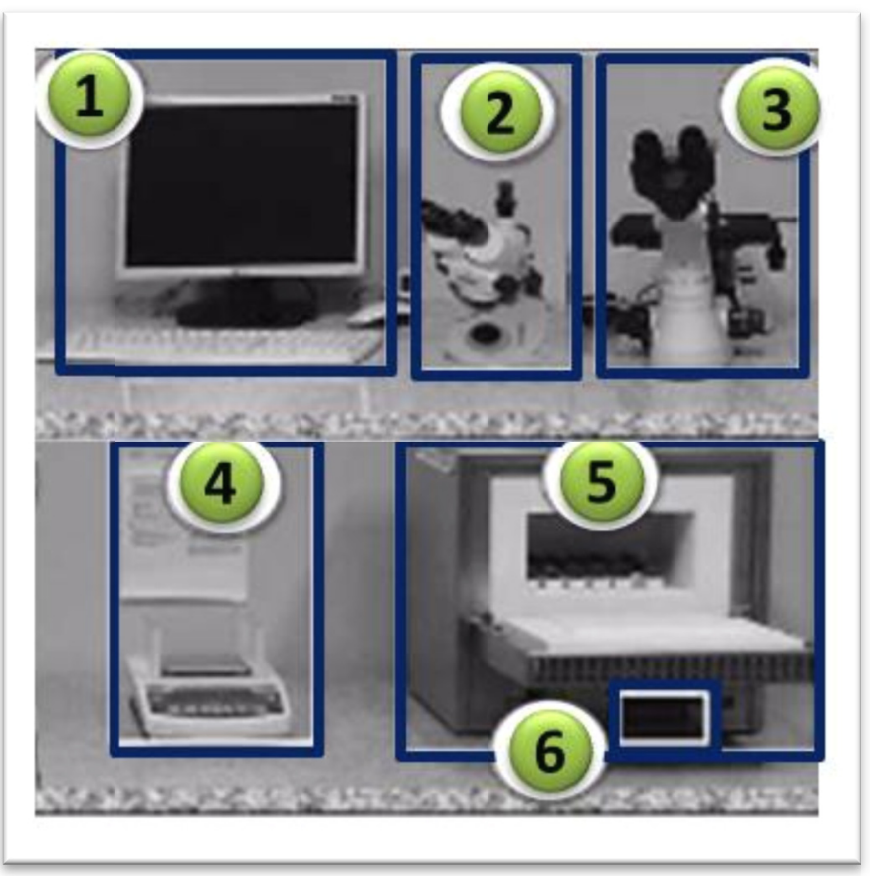

Fig. 7. View on high temperature corrosion stand: data registration (1), stereoscopic (2), Nikon LM(3), precision balance (4), L/05/12 furnace (5), HT industry programmer (6) [1]

\section{Results and discussion}

The results after the spraying process indicate, that for the process of obtained coatings with cooling is recommended to use micro-injector type A40. The obtained coatings were prepared in shortness time according to high velocity oxy fuel process. Reducing process time was approximately $40 \%$ in laboratory test conditions. The coatings obtained by hybrid method with one micro-injector type A40 had got fine-dispersive structure, low porosity (about of 3\%), and good density, comparable with the coating obtained by classical HVOF method. The microhardness of these coatings was of about $970 \mathrm{mHV}_{100}$ (Table 2).

The fine dispersive structure of coatings characterized good adhesion (Fig. 8). 
TABLE 2 the test condition for all obtained coatings (Fig. 9). A spallation

Microhardness and thickness of coatings

\begin{tabular}{|c|c|c|c|c|c|c|c|}
\hline \multirow{3}{*}{ 范 } & \multicolumn{7}{|c|}{ Average of 5 measurements } \\
\hline & \multicolumn{6}{|c|}{ Microhardness $\left[\mu \mathrm{HV}_{100}\right]$} & Thickness \\
\hline & 1 & 2 & 3 & 4 & 5 & Average & Average \\
\hline $\mathrm{S} 1$ & 878 & 928 & 954 & 924 & 993 & 935.4 & 436.86 \\
\hline S2 & 841 & 830 & 869 & 938 & 1190 & 933.6 & 454.42 \\
\hline $\mathrm{S}_{1 \mathrm{~A}_{40}}$ & 917 & 893 & 854 & 933 & 1284 & 976.2 & 438.20 \\
\hline${\mathrm{S} 2 \mathrm{~A}_{40}}$ & 825 & 930 & 836 & 924 & 1328 & 968.6 & 453.08 \\
\hline
\end{tabular}
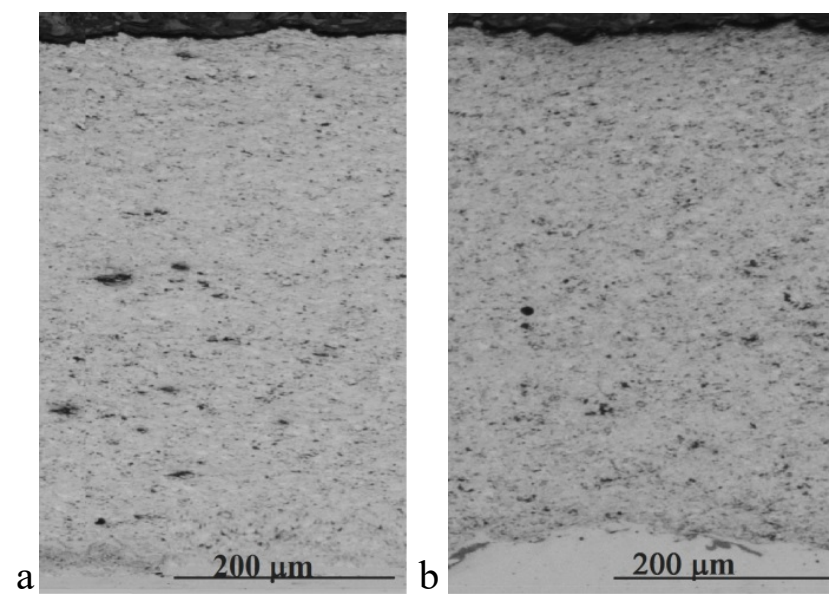

Fig. 8. Structure of coatings obtained by a) high velocity oxy fuel Sample S1 b) hybrid process - Sample S1 $\mathrm{A}_{40}$

The changes, as a delamination, exfoliation and surface cracking were not observed. The results presented in Tables 3-5, confirm good abrasion and erosion resistance of coatings. The results were comparable for all studied materials. Slightly better properties had got the coatings after the cooling process with micro-injector type A40, but the registered differences were within the margin of error. The mass change as a function of heating time showed, that all the tested coatings had got good corrosion properties. The oxidation rate low was comparable in process was not observed.

TABLE 3

Abrasion resistance of coatings

\begin{tabular}{|c|c|c|c|c|c|c|}
\hline \multirow{2}{*}{ 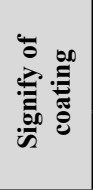 } & \multicolumn{6}{|c|}{$\begin{array}{c}\text { Abrasion resistance [g]: } \\
m_{1} \text { (mass of sample bevor test); } m_{2} \text { (mass of sample after } \\
1 \text { test); } m_{3} \text { (mass of sample after } 2 \text { tests }\end{array}$} \\
\hline & $m_{1}[\mathrm{~g}]$ & $m_{2}[g]$ & $\begin{array}{c}m_{1}[g] \\
\left(m_{1}-m_{2}\right)\end{array}$ & $m_{3}[g]$ & $\begin{array}{c}m_{\mathrm{II}}[\mathrm{g}] \\
\left(m_{2}-m_{3}\right)\end{array}$ & $\underset{\left(m_{I}+m_{I I}\right)}{\Delta m[g]}$ \\
\hline S1 & 35.4481 & 35.43452 & 0.01358 & 35.38603 & 0.04849 & 0.06207 \\
\hline S2 & 37.5643 & 37.552 & 0.0123 & 37.49801 & 0.05399 & 0.06629 \\
\hline $\mathrm{S} \mathrm{A}_{40}$ & 31.5114 & 31.50156 & 0.00984 & 31.45923 & 0.04233 & 0.05217 \\
\hline $\mathrm{S}^{2} \mathrm{~A}_{40}$ & 32.6713 & 32.6601 & 0.0112 & 32.62243 & 0.03767 & 0.04887 \\
\hline
\end{tabular}

TABLE 4

Erosion resistance of coatings at ambient temperature

\begin{tabular}{|c|c|c|c|c|c|c|}
\hline \multirow{3}{*}{ 施 } & \multicolumn{6}{|c|}{$\begin{array}{c}\text { Erosion resistance }[\mathrm{g}]: \\
m_{1} \text { (mass of sample bevor test); } m_{2} \text { (mass of sample after test) }\end{array}$} \\
\hline & \multicolumn{3}{|c|}{$\begin{array}{l}\text { at ambient temperature } 20^{\circ} \mathrm{C} ; \\
\text { rotation } 600\end{array}$} & \multicolumn{3}{|c|}{$\begin{array}{l}\text { at ambient temperature } 20^{\circ} \mathrm{C} ; \\
\text { rotation } 900\end{array}$} \\
\hline & $m_{1}[\mathrm{~g}]$ & $m_{2}[\mathrm{~g}]$ & & & & \\
\hline S1 & & & & & & \\
\hline $\mathrm{S} 2$ & & & & & & \\
\hline S1A & & & & & & \\
\hline $\mathrm{S}_{2 \mathrm{~A}_{40}}$ & 30.6617 & 30.6498 & 0.0119 & 30.62525 & 0.02455 & 0.03645 \\
\hline
\end{tabular}

TABLE 5

Erosion resistance of coatings at $650^{\circ} \mathrm{C}$

\begin{tabular}{|c|c|c|c|}
\hline \multirow{3}{*}{ 㑒施 } & \multirow{2}{*}{\multicolumn{3}{|c|}{$\begin{array}{c}\text { Erosion resistance [g]: } \\
m_{1} \text { (mass of sample bevor test); } m_{2}(\text { mass of sample after } 1 \text { test) } \\
\text { at elevated temperature }\left(650^{\circ}\right) \\
\end{array}$}} \\
\hline & & & \\
\hline & $m_{1}[\mathrm{~g}]$ & $m_{2}[g]$ & $m_{I}[g]\left(m_{1}-m_{2}\right)$ \\
\hline S1 & 35.2431 & 35.2297 & 0.01344 \\
\hline S2 & 34.2672 & 34.2546 & 0.01257 \\
\hline${\mathrm{S} 1 A_{40}}$ & 34.1107 & 34.0978 & 0.0129 \\
\hline $\mathrm{S}_{2 \mathrm{~A}_{40}}$ & 35.7413 & 35.7315 & 0.00979 \\
\hline
\end{tabular}

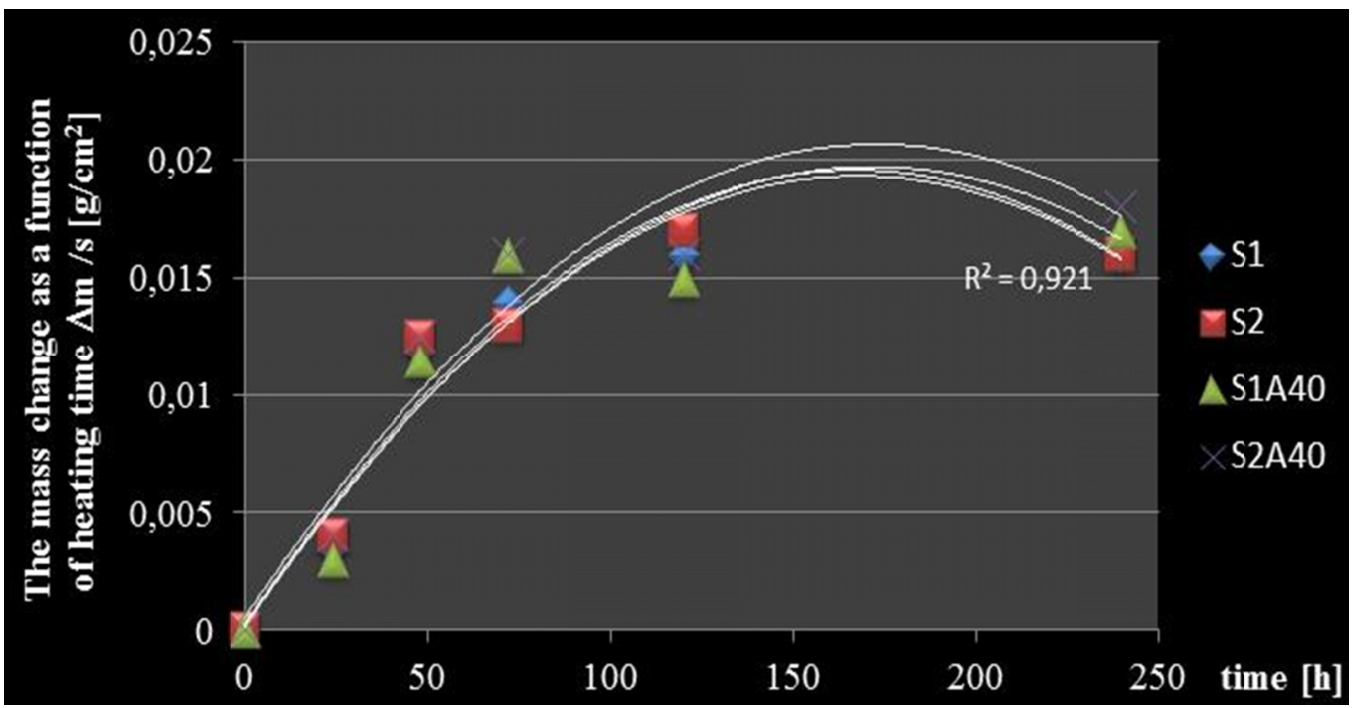

Fig. 9. Mass change as a function of heating time in oxidation test at $800^{\circ} \mathrm{C}$ 


\section{Summary}

The presented results after the spraying process indicate, that for the process of obtained coatings with cooling is not recommended to use micro-injector type A50 and B50 (consisting of two micro-steam diameter of $40 \mu \mathrm{m}$ ) The cooling process was too intensive. The intense drop in temperature leaded to exfoliation or cracking of obtained coatings during tests.

The hybrid process with micro-injector type A40 allowed to receive a coating of satisfactory utility properties. Presented studies confirmed that all obtained coatings are characterized by comparable properties of abrasive, erosive and corrosive resistance. This means that the parameters of the spraying process under laboratory conditions have been chosen correctly. Coatings prepared by HVOF techniques had properties slightly different from those produced by hybrid thermal spray method. As discussed in the study this resulted mainly from the characteristics of the processes and in particular the combination of particle velocities and temperatures. On the other hand, this also implied that properties of the coatings can be adjusted according to demands of the application at least to some extent.

Currently tests are conducted wider its application for technology of applying the thermal coating in order to shorten the time to pass between the application of successive layers of coating material.

\section{REFERENCES}

[1] B. Wielage, H. Pokhmurska, M. Student, V. Gvozdeckij, T. Stupnyckyj, V. Pokhmurskij, Surf. Coat. Tech. 220 (2013).

[2] L. Chang-Ji Iu, Y. Guan-Jun, Int. J. Refract. Met. Hard. Mater. 39 (2013).
[3] K. Szymański, A. Hernas, G. Moskal, H. Myalska, Surf. Coat. Tech. 268, 25 (2015.)

[4] G. Golański, A. Zieliński, J. Słania, J. Jasak, Arch. Metall. Mater. 59, 2 (2014).

[5] G. Golański, P. Gawień, P. Słania, Examination of Coil Pipe Butt Joint Made of 7CrMoVTib10 - 10(T24) Steel After Service, Arch. Metall. Mater. 57, 2 (2012).

[6] A. Hernas, The processes of destruction and protective coatings used in power industry, Racibórz, Polska (2015).

[7] Z. Zurecki, R. Ghosh, T. Mebrahtu, M.J. Thayer, S.R. Stringer, Automated substrate cooling system for HVOF coating operations, in: E. Lugscheider (Ed.) Air Products \& Chemicals, Maastricht, Netherlands (2008).

[8] A. Lisiecki, Metals 5, 1 (2015).

[9] T. Węgrzyn, J. Piwnik, B. Łazarz, D. Hadryś, Arch. Metall. Mater. 58, 2 (2013).

[10] T. Węgrzyn, J. Piwnik, J. Wieszała, D. Hadryś, Arch. Metall. Mater. 57, 3 (2012).

[11] R. Burdzik, P. Folęga, B. Łazarz, Z. Stanik, J. Warczek, Arch. Metall. Mater. 57, 4 (2012).

[12] W. Tarasiuk, B. Szczucka-Lasota, J. Piwnik, W. Majewski, Advanced Materials Research 1036, (2014).

[13] R. Burdzik, Ł. Konieczny, Journal of Vibroengineering 15, 4 (2013).

[14] T. Wegrzyn, J. Piwnik, D. Hadryś, Arch. Metall. Mater. 58, 4 (2013).

[15] T. Wegrzyn, J. Piwnik, D. Hadryś, Arch. Metall. Mater. 59, 2 (2014).

[16] A. Kurc-Lisiecka, W. Ozgowicz, W. Ratuszek, J. Kowalska, Solid State Phenomena, 203-204, (2013), Doi 10.4028/www.scientific. net/SSP.203-204.105

[17] J. Piwnik, D. Hadryś, G. Skorulski, Arch. Metall. Mater 59, 1 (2013).

[18] A. Lisiecki, Arch. Metall. Mater. 59 (4), (2014). 